\title{
Exploring the Chaos of Commodification: From the Arcades to the Cascades with Benjamin and Leopold
}

\author{
Timothy W. Luke
}

In this study, I work through ideas from Ben Agger on critical theory to develop a provisional exploration of how Walter Benjamin helps us understand the chaos of commodification. This analysis also unfolds as a thought experiment about the Anthropocene as economies and environments merge in today's planetary urbanization. To accomplish these goals, I also examine the merits of mapping Walter Benjamin's critique of capitalist modernity as well as Aldo Leopold's understanding of biotic community against the advent of the Anthropocene to elaborate a layered critique of built and unbuilt environments in the contemporary world-system.

Walter Benjamin (1892-1940) was an eclectic essayist, cultural critic, and aesthetic thinker, whose life unfolded in Germany during the Second Empire, World War I, the Weimar Republic, and Third Reich. Born in Berlin, he studied at the Universities of Freiburg and Berlin where he saw himself contributing to the outlines of a "cultural Zionism." During World War I, he studied at the Universities of Munich and Bern before earning his PhD in 1919. Along the way, he came to know, or work with, Heinrich Rickert, Rainer Marie Rilke, Gershon Scholem, Ernst Bloch, and Leo Strauss before becoming affiliated with the Institute for Social Research in Frankfurt. He continued to write on French literature, German drama, and metropolitan Europe as he interacted with Theodor Adorno, Max Horkheimer, Georg Lukács, Herman Hesse, Berthold Brecht, Kurt Weill, Hannah Arendt, George Bataille, and others, while he sought academic work in Germany. Living at times in Spain, Italy, Russia, and France, he began his Das Passagen-Werk (The Arcades Project) about the Paris Arcades in 1927, which was published posthumously in 1982. With Hitler's rise to power in 1933, however, he became an exile. Ultimately, he ended up in France after the 1940 German invasion, but was on the arrest list due to his Jewish identity. He committed suicide on September 25, 1940 in Catalonia after leaving his Arcades Project manuscript with Georges Bataille in Paris.

Aldo Leopold (1887-1948) was a contemporary of Benjamin, although faraway in the American Midwest. His love for the land led him from Iowa to the Yale Forest School where he graduated in 1909. Leopold started his career as a conservationist, teacher, and writer, working with U.S. Forest Service in Arizona and New Mexico. After being transferred to Madison, Wisconsin, Leopold refined his thoughts about wildlife management and published them as the first textbook in this field. That study led to his appointment to an academic chair in game management at the University of Wisconsin in 1933. With his family, he slowly cultivated the ecological restoration of an old farm on the Wisconsin River outside of Baraboo in Sauk County. At "The Shack," they replanted trees, and restored native prairie plants. Leopold began writing essays about his experiences there, which were posthumously published during 1949 after his death from a sudden heart attack in 1948. The essay collection, A Sand County Almanac, became one of the most widely read books about America's environmental heritage, and it remains a classic work in conservation thought, environmental ethics, and wildlife ecology.

Benjamin's fascination with the nineteenth century metropolis, especially the character of the flâneur on Parisian boulevards, and the material life in Paris' grand arcades, makes this comparison perhaps seem unlikely. His work sifts through the detritus of La Belle Époque, and he died in 1940 -- just as World War II intensified, and five years before "The Great Acceleration" (McNeill and Engelke, 2014) begins after V-J Day. Like Leopold's meditations 
on America's prairies, highlighting how urban spaces were being degraded in related ways, Benjamin's thought anticipates many of the harshest contradictions in today's anthropogenic environments. The dialectical interrelation in Benjamin's and Leopold's appraisals of cityscape with countryside, urban life and rural living, industrial and agricultural existence, mental and manual labor, strolling around urban streets and hiking out in wild country, in fact, reveal many improbable parallels between Benjamin and Leopold. At the same time, their thinking sets the stage for Ben Agger's explorations in critical theory, especially the "representationality" of contemporary capitalist critique in the "soci (onto)logy" of American society (Agger, 1989a). Like Agger, this study follows the Frankfurt School "to link economic with cultural and ideological analysis" (Agger, 1991: 22) in explaining variations in the critical representation of "nature" and "culture" in global capitalism after Marx.

The historic shift around the North Atlantic basin towards greater urbanization after 1815 coevolves with the testing of new freedom culturally, economically, and technologically. These fresh currents of historical change colliding with once obdurate biological contingency, as Foucault observed, (1990: 135-159) transforms human freedom as well as nonhuman necessity, which Agger mapped out as "fast capitalism" (1989b). Benjamin's artful reinterpretation of the city and country in global exchange also echoes in Leopold's writing. His meditative walks in the countryside led him to develop a "land ethic" for humans to coexist with nonhumans more justly in urban and rural biotic communities. An insight from Adorno links these observations from Agger, Benjamin and Leopold. At the dawn of the nineteenth century, "philosophy had succeeded in refining the concept of natural history by taking up this theme of the awakening of an enciphered and petrified object" (Adorno, 1984: 119) in the eternal transience seen in nature by philosophers, physicists or poets. Hence, "the deepest point where history and nature converge lies precisely in this element of transience. If Lukács demonstrates the transformation of the historical, as that which been, into nature, then here is the other side of the phenomenon: nature itself is seen as transitory nature, as history" (Adorno, 1984: 119).

Benjamin, in turn, adds his own twists to allegorical reasoning about cultural significance as "the playing out of a particularity; it is expression," and Adorno asserts this turn reveals how the basic qualities of necessity and transience for "the Earth signifies nothing but just such a relationship between nature and history all being or everything existing is to be grasped as the interweaving of historical and natural being" (Adorno, 1984: 119, 121). The causes and effects at play in the Anthropocene's interwoven historical and natural becoming are a degraded environment, a significant wealth gap, uneven development, and depleted fossil fuels. These links of history and nature are the markers of what "truly is an age of decline, as evidenced by these social problems of modernity and postmodernity" (Agger, 1991: 9). Leopold's musings about the biotic community in the sand hill country of rural Wisconsin, in turn, takes a parallel trail to Benjamin's wandering in the Arcades of Paris.

By the time Benjamin took his own life, the first stirrings of the Anthropocene were recasting Nature. Between 1940 and 1945 ,

Human beings had already violated the Earth's 'natural laws' by staging a controlled nuclear chain reaction. By 1945, the machining of rare natural elements, like uranium, into explosive devices, human beings begin to ward nature by accelerating matter into new artificial realms of transuranic de-nature, introducing into the environment many new materials, like neptunium and plutonium that hitherto did not exist in Nature as it had been known. . Nature now becomes in many respects truly anthropogenic, not autogenic or theogenic, and the powers causing its anthropogenesis also arguably begin to implode many existing cultural, political, and social systems predicated upon stable natural realisms (Luke, 1996: 499).

The nuclear revolution is the anthropogenic core of the Anthropocene, and the Great Acceleration that follows it degrades many existing environmental conditions of human cultural, economic, political, and social practices (McNeil and Engelke, 2014).

A new biopolitical nexus, then, takes hold after 1945 with the Great Acceleration's continuous technological, social, and cultural remix of the natural as the historical. Plainly, Benjamin anticipated these shifts in Paris, Moscow and Berlin, or "the city." Now, however, even these urbane centers and quiet rural peripheries, like Wisconsin's Sauk County, shift shapes together. The not-yet-urban, never-urban or once-urban, as spatial expanses of nature, manifest of the extraordinary historical machinations Benjamin scrutinizes in the metropolis. Much of what he examines in his Arcades Project, or Passagen-Werk, is from a time in which barely ten cities had populations of one million, and much of the world was predominately rural. As some debates about the Anthropocene note, this number of cities now tallies over 300, and over half the planet's human inhabitants live in the vast networks of urban sprawl underpinning "planetary urbanization" (Brenner and Schmid, 2014). The semiotic systems of fast capitalist exchange now coevolve with this hyperurbanization. As Agger maintains, "simplification oversimplifies a complex 
reality," and these aesthetic, critical and sociological dialects cannot escape how "language in structuring reality is structured by it, thus becoming a material force" (Agger, 1989b: 156).

Aldo Leopold's "land ethic" already acknowledged this growing citification of wilderness by enjoining each human to join his or her "land-community" as a "plain member and citizen of it" (Leopold, 1966: 240) in "the country." His call to see biotic successions in the landscape "not only of plants and soils, but of the animal community subsisting thereon" (Leopold, 1966: 242) is an appeal to avoid wrecking the land-community, while at the same time being an invitation to walk among its coinhabitants to acquire a shared spirit of conservationist coexistence. While Leopold admits his appeal was not widely heeded, he maintains that "conservation is a state of harmony between men and land" (1966: 243).

It is fair to ask if the whole Earth for humanity is increasingly deruralized, deagrarianized, and denaturalized mangles of urbanizing growth in which one finds not identical, but also not dissimilar, traces of the tendencies Benjamin tracked in the late nineteenth and early twentieth century metropolis. Such urbanization is, in fact, another ominous indicator of ecological degradation, evolving in parallel with greenhouse gases: carbon dioxide as parts per million in the atmosphere rose from around $280 \mathrm{ppm}$ in 1700 to only 293 ppm by 1900 (eight years after Benjamin's birth). In 1940 when Benjamin died, the level had rapidly risen to 307 ppm; and, in 2009, it has risen to 388 ppm. (Breeze, 2005: 11). In April 2017, it hovers around 410 ppm, and all life forms on Earth live in a gas greenhouse.

Pulling the planet under this increasingly denser gas greenhouse reshapes the conceptual distinctions Adorno drew between "Nature" versus "Society." Life on planet Earth is marked by greater levels of "artifactuality" in the natural facticity of its environments. Nature citified under the gas greenhouse still can be seen, especially by environmentalists, as raw, untamed or wild, but these attributes now are more conditional, provisional or complex under the accumulated atmospheric detritus of fossil fuel civilization spinning out its shrouds of pollutants around the world.

Amid the exhausted compound by-products of today's biopower, "the urban revolution" appeared in 1970 only as "a horizon, and illuminating virtuality" (Lefebvre, 2003: 17). It is more easily identifiable in today's deruralizing/ overurbanizing ways of life. While "the urban" in Lefebvre's analysis is abstract, its fields of force pull together the mangles of rapid climate change -- from cap-and-trade greenhouse gas markets, genetically modified food or Greenland's glaciers melting to mass global extinctions, motorcar biofuels from trash or massive Montanan nature preserves managed by mass media moguls. The Anthropocene clearly is another aspect of "speeding up fast capitalism" (Agger, 2004) in which the energy, information, labor, and material needed to produce the instantaneity of globality leave noxious by-products as enduring planetary degradation (Agger, 2004: 6). Today's citified countrysides, in the meantime, bring the world's environments and their overburdened inhabitants the mystified "green goods" of sustainability, smart growth, and slow cities. These myths of sustainable development, however, shroud environmental ruination refined from organized corporate green washing.

Benjamin, therefore, then provides counter-intuitive anchor points to discuss ecology, environmentalism or Nature to the degree he regards "the city" as the essence of capitalist modernity, industrial management, and scientific materialism. Because the city is the matrix of modernity for Benjamin, urban life also "encapsulates the characteristic features of modern social and economic structure, and is thus the site for their most precise and unambiguous interpretation" (Gilloch, 1997: 5-6). Whatever the city marks, and wherever or whenever those marks are made beyond the city, one finds useful registers for a critical reappraisal of capitalist modernity, including the Earth's backwoods, countryside or wilds.

Another definitive sign of citification in the wilderness appears in Aldo Leopold's fusion of "a civic life" with "the countryside" in his Sand County Almanac. Implicitly affirming Benjamin's realization that Schmitt's sense of sovereignty uniquely extends to the state the power to be "Lord of all creation" (Benjamin, 1985: 85), Leopold stands ready to serve the state as a great law-giver, if not virtuous tyrant, by retraining souls and societies in the virtues of "land care." Anxious about the unpredictability of anarchic market forces, accidental historical contingencies, and allied blocs of railroad, banking or financial institutions all eager to superexploit the environment, he saw new social forces at work that aimed to statalize/citify "the country" as "land." In his green manifesto to propound "a land ethic" and bless "citizenship for all beings," however, there lurks the technoscientific proclivity for "green governmentality" (Luke, 1997) artfully to place this ethical polis within any paddock or pasture.

To a degree, the exurbanized spatialities of Wisconsin's Sauk County anchor in Leopold's thinking what Benjamin regarded as "the restoration of order in the state of emergency: a dictatorship whose utopian goal will always be to replace the unpredictability of historical accident with the iron constitution of the laws of nature," while, at the same time, deploying an ascetic credo of outdoor virtues "to establish a corresponding fortification against a state of 
emergency in the soul, the rule of the emotions" (Benjamin, 1985: 74). The tensions building between these spaces also track Leopold's implicit citification of the wilds in a historic compromise of values "achieved by reappraising things unnatural, tame, and confined in terms of things natural, wild, and free" (Leopold, 1966: xix).

Once glassed-over by greenhouse gases, and then monitored for its degradation via commodification, untamed natural wilderness can be more easily regarded as a domestic artificial commons. When making this citified shift in thinking, Leopold hopes humans would see their shared cultural coexistence with non-humans: "When we see land as a community to which we belong, we may begin to use it with love and respect. There is no other way for land to survive the impact of mechanized man, nor for us to reap from it the esthetic harvest it is capable, under science, of contributing to culture" (Leopold, 1966: xix).

The rise of this "second nature," or alienated labor and frozen capital reified "under science," as Leopold suggests, out in the boondocks of bourgeois spatiality was anticipated by Marx and Lukács. They also regarded these domains as extruded standing reserves for modernity. Adorno notes, "Lukács already perceived this problem as foreign to us and a puzzle to us," and, as a result, awakening these inward, estranged, complex meanings becomes "what is here understood by natural history. Lukács envisioned the metamorphosis of the historical qua past into nature; petrified history is nature, or the petrified life of nature is a mere product of historical development" (Adorno, 1984: 118). As these reified market conditions shape how natural history develops, then the petrification of historical products and by-products in nature also clearly becomes more common. This ruination of spirit, the body, and nature itself, in turn, provides a crucial vantage point to reappraise environmentalism in the twentieth and twenty-first centuries.

\section{From the Arcades to the Cascades}

As "the historical" exceeds the confines and constraints of "the biological" during the nineteenth century (Foucault, 1990: 135-159), Nature and Society become, in many respects, "the environment," or flexibly mangled assemblages of both natural and social forces, which gels as biopower (Luke, 1997). These forces do not accelerate until the closing of many old imperial frontiers in the Americas, Asia, and Africa around Benjamin's birth in 1892. Nonetheless, the origins of mainstream environmental thinking during the closing of the American frontier in the 1890s indicates how the simultaneous rapid urbanization, industrialization and acceleration of everyday life push the ill-effects of deruralization, deagrarianization, and detraditionalization into everyday life for more and more of the Earth's growing human populations.

Despite Leopold's idylls about Nature in the Wisconsin woods, the "great out-doors," "wilderness" or the "environment" are becoming hyperurbanized by the mid-twentieth century. Materially repositioned as complex objective conjunctions of natural, social, and historical forces, they are mentally, at the same time, expressing a salient "dream-and wish-image of the collective" (Benjamin, 1999: 905) caught in the "lowly in-doors." Once historicized in the (con)fusion of the biological and the social, Nature can be regarded "like Janus: it has two faces" (Benjamin, 1999: 543) that express opposing and complementary tendencies in dialectical tension. Where others wish to see only authenticity in the environment, one plausibly can argue with equal determination that is more ambiguity in play here as artifice pervades the environment's key qualities.

Benjamin asserts, and Buck-Morss (1989: x) underscores, "in an era of industrial culture, consciousness exists in a mythic, dream state, against which historical knowledge is the only antidote. But the particular kind of historical knowledge that is needed to free the present from myth is not easily uncovered. Discarded and forgotten, it lies buried within surviving culture..." What is buried, how it is forgotten, and why it is discarded are challenging questions. Such knowledges often are regarded as neglected, invisible or buried due to their uselessness to anyone in power.

Buck-Morss' detailed "dialectics of seeing" from Paris arguably must now be supplemented with another approach for "seeing dialectics" beyond Paris to fathom how the consciousness and experience of wilderness, Nature, environments, and ecology exists in mythic dream states of a processed world.[1] Benjamin's Arcades Project begins this remarkable undertaking; but, it is fragmentary, and polyvalent in its purposes. Centered on Paris, it speaks about more than that one city in deciphering of capitalism from the detrital stuff and daily truck in its great enclosed markets. The Arcades of Paris were close to Benjamin, and that city was as good a place as any to explore for him. What about today? 
I reside thousands of miles from Paris, France, but I live near Pearisburg, Virginia -- the county seat of Giles County where there is a striking park and waterfall, often visited and photographed, on Little Stony Creek, which is known as "the Cascades." Here, my analysis continues the critique of the commodity form in the early years of twenty-first, and last years of the twentieth, centuries by reappraising this natural site's reified ruinations. The merits of "a Cascades Project," positioned along with "the Arcades Project," are considerable. One also should bear in mind that these cascades are but one of many. All across the USA from the Appalachian to the Cascade Mountains, hundreds of other "Cascades" are out there to be discovered and deciphered in comparable terms, allowing one to leverage a fortuitous interplay of homophony and propinquity to explore the issues raised by Benjamin. [2]

The Cascades National Recreational Trail lies in the George Washington and Jefferson National Forests in Virginia and West Virginia with about 1.8 million acres of public land. Surrounding this site, the Mountain Lake Wilderness laps into two states and three counties with over 11,000 acres of fairly roadless terrain with old growth forest straddling the Eastern Continental Divide.[3] These ranges of raw nature, however, are at the same time an elaborate anthropogenic apparatus dedicated to resource management, land conservation, and recreational industry. Turning to the Cascades for this study is apropos, since they can reframe seeing dialectics.

This waterfall and forested watercourse lies in the Little Stony Creek Valley of Giles County, Virginia at the base of Salt Pound Mountain the Appalachian chain. While it is not being mined itself now, Salt Pond Mountain and sister peaks near-by and not so far away in Virginia and West Virginia are being systemically scraped down to bed rock to remove fossil fuel from their coal beds -- millions of tons have been shipped around the world to be burnt in coal-fired power plants, steel foundries, space heating systems. To some extent, the gas greenhouse now shrouding the Cascades as well as the entire planet is glazed with burnt fossil fuels extracted from the same mountains being remade to operate as attractive development schemes, like state parks, county campgrounds, local curiosities, and all the other travel-centered distractions of the leisure industries embedded in national recreation areas. The apparent harmony of Nature and Society in the mythic materialities of the Cascades clearly mystify what is an "externally contradictory social order, both robbing labor and despoiling the environment” (Agger, 1992: 8), although few pilgrims on the trails have those thoughts as they wend their ways through natural attractions and social artifice in search of an aura of authenticity.

Again, Adorno provides perspective for thinking about the Arcades by reversing the polarities in observations he made about Benjamin; namely, he had "as no one else, the ability to regard historical things, manifestations of objectified spirit, "culture," as if they were nature" (Adorno, 1970: 17). With regard to the Cascades, then, one must begin to gauge apparently natural things, manifestations of necessity itself, or "nature," as if they are "culture" as very good conditions for seeing dialectics.

\section{The Cascades Near Pearisburg}

Working parallel to Benjamin, one can regard the places and spaces of the Cascades as countless boulevards exteriorized, not unlike those coming out from the interiors of cities and towns, until they overlap in countrysides. Such cascades coevolve with other new developments of affluent industrial production and by-production: the glassed-over, walled-up and spread-out by-ways of built and unbuilt social formations on the Earth under the gas greenhouse. The occupants and owners join together in ventures that accelerate the citification/deruralization of the world's overurbanized workings. Sometimes at the end, other times at the start, and elsewhere alongside, the cascades of planetary urbanization are evolving elaborate markets. In many respects, the paths to the Cascades are not unlike city byways; and, citified sprawl crawls closer, deeper, faster into every crack, crevasse, and cataract of the Cascades — a processed world maximized and minimized on multiple scales.

Such parallels are not necessarily "the locus classicus" for identifying nature, but they allude to all the rifts and conjunctures that express late modernity up close, faraway, right now, once before, up ahead, out behind, quite deep, and real high. Following Benjamin's analytical lead at the Arcades, one can turn to an "illustrated guide book" on the Cascades, published today as a web page, which captures this uniquely processed appropriation of the wilderness. Cascade Falls draws visitors from around the world, and the Giles County web site [http://virginiasmtnplayground. $\mathrm{com} /$ cascades/] provides a colorful description of its overindustrialized panoramic qualities: 


\section{$\underline{\text { Cascade Falls }}$}

Cascades Recreation Area, Jefferson National Forest, Pembroke

For more information call:

$540-552-4641$

About 150,000 visitors a year visit the Cascades. Without question, Cascade Falls is one of the most beautiful waterfalls in Virginia and possibly on the entire East Coast. Little Stony Creek falls over a vertical cliff in several different streams. Several streams cascade a couple times on the way down while others fall the whole distance of the falls.

The $69 \mathrm{ft}$. falls crash into a large pool surrounded by two hundred foot cliff walls from which large ice formations hang in the winter. The scene is both breathtaking and peaceful as the falls combine both power and beauty. The falls are also fairly easy to view, with wooden stairs and platforms on one side of the pool allowing a visitor to get very close to the falls as well as allowing a photographer many different angles for photographs.

\section{About the Hiking Trail}

The Upper Trail is a beautiful hike with scenic, aerial views of Little Stony Creek. But, it's only half of the well-loved fourmile loop. Picking its way along the banks of Little Stony, the Lower Trail pauses at the edge of buggy backwaters and hangs over gushing cataracts. It winds its way through families of moss-covered boulders and cuts through rhododendron thickets. The roar of Little Stony is its constant companion as it climbs toward the main waterfall. The spectacular views from the Lower Trail are as beautiful as the Cascades. It takes four bridges and innumerable stone steps and walkways to give visitors this experience. The original trail, built in the 1960s, was so artfully constructed that it seemed to belong there.

In 1996, melting snow and heavy rains turned Little Stony into a raging torrent. When the waters receded, three of the bridges and much of the trail were missing. The U.S. Forest Service allocated $\$ 400,000$ to rebuild the trail and make improvements at the trailhead. They turned to Charlie Dundas, whose company, West Virginia-based Tri-State, had done a good bit of repair work to the trails over the years. Dundas said the Forest Service liked his plan to rebuild the trail without heavy equipment, and thus disturb the land as little as possible. When he began, a quarter of the two-mile trail had been destroyed.

"Certain key areas were just totally gone," Dundas said. "It [the flood] scoured it down literally to bedrock." In some places, the old trail was resurrected, in others all new trail was built. A few ghosts of the old trail remain - stone steps that survived the flood but now lead nowhere.
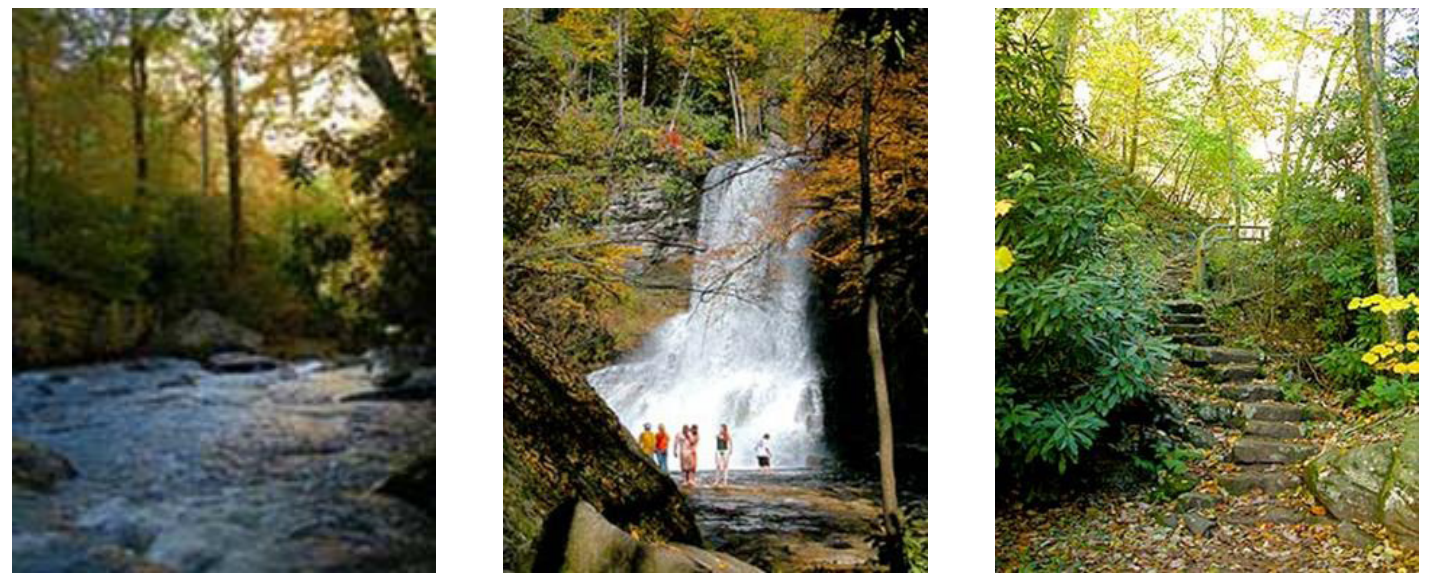

The new bridges are mighty structures, supported by enormous beams and enclosed on both sides with log railings. They should have at least a fighting chance if Little Stony floods again. Tri-State sought to restore not just access, but also the character of that original trail. The countless stone steps seem at home here and so will the bridges once they've been smoothed and stained by a few Giles County winters. And, just like the old trail, there are plenty of roots and rocks to trip over and slick spots to slip on.

The closer the trail gets to the big waterfall, the more work there was for Dundas. Here the trail clings more desperately to the steep banks of the gorge. Raised stone walkways, held together with steel pins, were built to make it passable. But the rougher the terrain gets, the more impressive the sights. Furious white water rips between boulders to fall churning into a pool below. Up ahead, a small stream tumbles down the side of a cliff into Little Stony. 
Finally, the upper and Lower Trails meet and ramble on to a stunning climax. Vegetation and an enormous boulder conspire to hide the falls from sight for as long as possible. When hikers round the boulder, the Cascades suddenly appear, roaring for attention. The waterfall reigns in this bowl-shaped arena it has carved from the mountain. Little Stony's rushing waters leap from the edge, cascading down the rock wall and landing in churning, misty turmoil in the pool below. From the rocks midstream or the observation deck near the top, the sight is spectacular enough to merit the thousands, if not millions, of photos that have been taken.

Time to go home. Tradition demands that the Upper Trail be taken back. From its lofty perch on the side of the gorge, it provides hikers with a new perspective of Little Stony. Its direct route is an asset now, as it leads the weary back to their cars and a cold drink in Pembroke.

[http://gilescounty.org/cascades.html]

As these places are continuously valorized on the internet as an alluring nexus of recreational convenience for "Outdoor Adventures," the Cascades shine worldwide with webs of phantasmagoric allure.

Here, one does not see the flâneur on the trail. Instead, there is "the hiker," or the randonneur (or randonneuse), planning a randonné to the Cascades. He or she got information up-front on "How to Find It," along with "Driving Directions," and "For more information Call: 540-552-4641 Jefferson National Forest." This information is not about the wilds; it is instead cut-and-dried directions through elaborate and embedded built environments. The ruse of nature remains since the original trail is "so artfully constructed that it seems to belong there." The rush of Culture, however, flows through "mighty structures" all are "enclosed on both sides," which hint at the easy processed urbanity of Arcades-like metropolitanized spatialities nesting in the woods.

\section{The Randonneur and Ruins}

Amidst the Arcades, "the flâneur plays the role of the scout in the marketplace," and, "as such, he is also the explorer of the crowd" (Benjamin, 1999: 21). Out in the Cascades, one does not see the stroller, but rather "the hiker." Of course, the randonneur is an avid scouting explorer, but this urbanized subject tramps along each nature trail, white-water run, pristine seashore or distant ridge seeking to affirm a slightly different pre-processed quality. For the flâneur, "the newness for which he was on the lookout all his life consists in nothing other than this phantasmagoria of what is "always the same." (Benjamin, 1999: 22). The randonneur seems intent on another range of phantasma from wilderness preserves -- or the affirmation of more, greater, and better open space that is "the same as always." For Benjamin, "the final voyage of the flâneur: death: Its destination: the new" (1999: 22). Perhaps for the randonneur, the continuing trek is life, or birth/maturation/ reproduction/death? And, so the destination of this modernity is "always the same," but also the continuously renewed "soci(onto)logy" of postindustrial living (Agger, 1989a). The phantasmagoria of the Cascades are real, even though their contents are more distributed, farflung, and remote than concentrated, right-up-close, or near-by.

If it is true that for the flâneur, the "crowd" Benjamin sees is but a loose veil hiding the "masses," then for today's hiker, or the randonneur, "the outdoor recreational public" is at least one contemporary expression of more variegated, numerous collective agglomeration of the "masses." Edward Abbey's (1968) diatribes against "industrial tourism," and his fascination with the conditions of "desert solitaire," also express this shift quite effectively. In this regard, Abbey's visions of the randonneur highlight another effort, like those of Benjamin, to remember that "in every era the attempt must be made anew to wrest tradition away from a conformism that is about to overpower it" (Benjamin, 1969a: 255). Edward Abbey's fictional works with their accounts of many arduous hikes across desert wastelands (Luke, 2007: 5-28) often define the essential qualities of the contemporary randonneur. Purposely anarchistic, Abbey $(1968 ; 1977)$ propounds an idiosyncratic vision of the arts of "hiking" that is loaded with conflicted emotions about tramping through planetary urbanization's contradictory spaces of ruination and conservation.

Leopold's hikes across the Wisconsin sand hill country, Southwestern deserts, and Midwestern farm lands of America echo a similar critical spirit. Despite Leopold's allegedly authentic laments for Nature's alleged purity on his many hikes, Lefebvre nails a bitter truth about many environmentalists' aesthetic conceits: “everyone wants to protect and save nature; nobody wants to stand in the way of an attempt to retrieve its authenticity. Yet at the same time everything conspires to harm it" (1991: 30-31). As the gas greenhouse heats, the wilds around Moab, 
the Wisconsin sand hills, and the woods near Pearisburg serve as rich registers in which as "each illusion embodies and nourishes the other ... the rational is thus naturalized, while nature cloaks itself in nostalgias which supplant rationality" (Lefebvre, 1991: 30).

In speaking as Nature's voice in the Utah canyon country, Abbey states "my sole purpose has been a private and egocentric one. I have no thought of serving others; such ambition is beyond both my intention and my powers. I am myself the substance of the book" (1989: xiv). On the other hand, Leopold's meanderings around Illinois, Wisconsin, Iowa, and Arizona are more openly public-spirited treks through the wilds to join "in conversation" with Nature. Admiring both animals and plants, like the birds and squirrels he found in Arizona's mountains, Leopold's land ethic moves him to regard non-human beings as "poker-faced but exuding emotion with voice and tail, told you insistently what you already knew full well: that never had there been so rare a day, or so rich a solitude to spend it in" (Leopold, 1966: 133). By hearing conversations of sorts out in the wilds, the randonneur that Abbey or Leopold discuss approximates, in some ways, a flâneur. But his or her boulevards are anywhere the boulders, big cats, brush, box canyons, and backwoods ramble.

To revalorize accumulation without end, however, the recreationist management machine also focuses maximum attractive force to enable each and every randonneur to extract maximal full value from whatever wild corner of the global market any randonné brings him or her out in the backwoods. Pure ruggedness is then eclipsed by industrial tourism. Planetary urbanization spins up multiple streetscapes. The affordance of multiple alluring angles for photography, paths for easy access, steady bridges over watercourses, and convenient stair steps in the woods as the trail experience gels into a standard package -- leaping waters, spectacular sights meriting millions of photos from lofty perches on the gorge, a dip perhaps in cool churning pools, and then cold drinks at trail's end.

While no single randonneur reproduces the same trek down the trail, there is a subtly normalized script for Cascades conduct. No matter the season, photographs valorize, reify, reproduce, and accumulate the benefits of a hike for any and all who venture to this faraway place in these staged spaces. Just as the department store made use of the flânerie to sell goods, so too do such recreational sites of the Department of Agriculture's U.S. Forest Service mobilize the randonneé to energize the national market.

Randonneurs believe they are intrepid and inventive visitors, viewers or voyagers, but do they only routinely enact their outdoor behavior, black-and-white photo art prints, back-countryness or banal backpacking blogs as buyers of naturalized goods and services? Sited in a world evolving into the Anthropocene amid the materiality of modernity, the Cascades are a striking example of how today's cultural, psychic, social, and technological problems arise "due to wealth, not poverty" (Agger, 2011: viii). The Cascades are studied and situated body work, as Agger asserts has been developed "to combat sedentary lifestyles" or "even finding meaning in our daily existence" (Agger, 2011: viii). Therefore, the randonneur remains an ambivalent figure.

Ruination also runs rampant all around the Cascades. [4] Amidst what might seem to be an iconic green anchor point, one must ask if what is experienced here are, as the surrealists would offer, more "revolutionary energies" thrown off the latest "outmoded objects" under the gas greenhouse of citified global environmental management. No longer a realm of raw wild ruggedness, but instead a nationalized recreationist area under 24x7 GPS surveillance, are the Cascades also among "the objects that have begun to be extinct" as they too "fall from favor, slow in circulation or drift into disuse" (Benjamin, 1997: 229)?

With the Arcades, Benjamin pulled those commercial by-ways from their embedded dispositions in the early metropolis, bringing them face-to-face with the early twentieth century's chaotic confrontations of capitalism and communism, prosperity and poverty, progress and stagnation. To shake individuals from the phantasmagoric myth of commodification into a critical alertness, Benjamin illustrates how in ruins, like the Arcades, "history has physically merged into the setting. And, in this guise, history does not assume the form of the process of eternal life so much as that of irresistible decay" (Benjamin, 1977: 177-178).

Desolated, discarded or disused ruins lose their sizzle, while petrifying at the same time traces of times now past, lives once popular now lost, and commercial trends that since have turned another direction. With the Cascades, comparable changes are in motion. The strenuous life, afternoons in the woods, the day on the trail or minutes of wonder at the foot of waterfall -- are these moments also now petrified into the setting? Ruins are the stuff of everyday life going beyond stuff, blown away in bits, virtualized for $24 \mathrm{x} 7$ access, and natural wonders are no guarantee of anything special. Indeed, fewer and fewer people willingly leave their mini-vans or modern houses to wander in the woods where they would be without air conditioning or video games.

Out on the trail, one senses strongly "residues of a dream world," which are essential, as Benjamin (1986: 162) asserts, for "the realization of dream elements in waking" as the substance behind, 
the textbook example of dialectical thinking. For this reason dialectical thinking is the organ of historical awakening. Each epoch not only dreams the next, but also, in dreaming, strives toward the moment of waking. It bears its end in itself and unfolds it-as Hegel already saw-with ruse. In the convulsions of the commodity economy we begin to recognize the monuments of the bourgeoisie as ruins even before they have crumbled (Benjamin, 1986: 162).

Today, the wilderness and the city are both subjected to ruination. Ruins are essentially a reciprocating cycle of animation and deanimation, excitation and exhaustion, acceleration and deceleration, charging valorization with their preruined and postruinated energies. Creative destruction moves along these vectors of value-destructively creating new preruinate sites as well as creatively destroying postruinations at the nexus of exchange.

Benjamin's rueful insights about Paris and the complicated speculations about its decline in his Arcades Project see this couplet as "a symptom of the fact that technology was not accepted," and, at the same time, "these visions bespeak the gloomy awareness that along with the great cities have evolved the means to raze them to the ground" [c 7a, 4] (1999: 97). Anxieties about the wild today parallel this observation. While the first diktat of federal delimitations defining national parks, monuments, and wildernesses can be admired, the coincident policing of their flora and fauna, resettlement of any human occupants, and measured inventory of the natural resources stockpiled therein is a telling marker of planetary urbanization (Keller and Turek, 1998; Spence, 1999; and, Schrepfer, 2005). Despite all the legal protections for the wilds created since Reconstruction, a global economy has evolved the power and will to efface, ignore, or neglect them, if and when needed.

The Cascades track the same rise and fall as the Arcades with their celebratory embrace of the modern materiality. As Benjamin suggests, the Arcades of Paris and so many other major European cities, emerge in the 1820s as centers of fashion-driven mass consumption, and their initial condition of operation is the rise of the textile trade, creating centers of commerce in various luxury goods, which also could be illuminated in vast spaces day-and-night by gas lighting. Their second condition rests on the inception and proliferation of iron as a common building material, bringing new industrial techniques and materiel into architecture at world exhibition, ordinary street blocks, and infrastructural edifices.

Even though all are prompted to regard the Cascades as a green escape to the untouched nature of a wilderness getaway, is the entire site an organized exurban simulation of all the above? The paths to and from are bucolic boulevards often surfaced and/or fenced from the well-organized parking lot to the visitor's destination, namely, the Cascades themselves. Because it is outdoors, one must admit traces of Nature remain: squirrels abound, snakes might be seen, and skunks can be smelled. In so many other respects, however, this government-run park setting is not unlike a mall walk exteriorized, displaced, transposed into other corners of the anthropogenic/anthropocentric/ anthroponomic environment.

The spectacle is "natural," but its programmatic substance is normalized conduct organized around the commodified, reified, packaged time/space/materiel/energy commerce to transit to, through, around, and from the Cascades. Particular gear is specified for the engagement: hiking shoes, canteen, Gortex jackets, sunscreen, field glasses, map, fishing rods, camera, picnic lunches, poncho, bathing suits, towel, first-aid kits, guidebook, trash bags, backpack, etc. Those on the Cascades trails are far beyond being merely a flâneur, they are playing out the packaged outdoorsy roles of the randonneur.

\section{Tourism in an Age of Mechanical Reproduction}

Abbey or Leopold could unlock the core of industrial tourism from a cryptic sentence-as recorded by Benjamin —in Jacques de Lacretelle's "Le Revéur Parisien" from Nouvelle Revue Française (1927) which states: "for our type of man, train stations are truly factories of dreams" (Benjamin, 1999: 849). While this observation is true in many ways for multiple reasons, the industrial tourist feared by Abbey, when boarding the train to the Yukon, Yosemite, or the Yellowstone, has been indeed well-trained. Each line of flight stations them to coproduce his or her dreams of natural destinations, panoramic experiences, or unnatural speedy transit to through, and for the domination of Nature via personal embeddedness of iron infrastructures, photographic stylization, and constructed cascades in the Earth as vast velodrome. With the automobile, airplane, motorcycle, motorboat, snowmobile or jet ski, any landscape soon becomes a mechanized autorama for a wheel-borne tourist consciousness in the latest style and form of each industrial tourist's dreams.

Gripped by a site-specific script of green conduct, the dictates of this special discipline express another moment 
of everyday governmentality. The well-concealed panorama, the rescued fauna, the endangered flora, and the preserved wilds spin together around the Cascades. Its photographic images in alliance with the stupefied multitude, as Baudelaire once feared, are let fly for they can "hasten to enrich the tourist's album and restore to his eye the precision which his memory may lack" just as it already has been let to "adorn the naturalist's library, and enlarge microscopic animals" (cited in Benjamin, 1999: G92).

Ironically, such cascadification in global citification also fuses together Louis Daguerre's two great inventions: the dioramic spectacle and industrialized photography. As an industrial tourist, the visitor/viewer/voyager is freed from sitting in a small amphitheater to witness staged light shows, staged plays of days, and unreal flights of time. Cascadification in some respects daguerreotypes the masses with new plated folkways for an outdoor recreational public. Most nature preserves are amphitheatrical, the stage always is shifting, and the lights of photographic apprehension vary. The well-designed lines of rapid transit through these urbanaturalized sites nicely exhaust the multiplicity of energies powering industrial tourism. As Benjamin records, an account of such daguerreotyped experience -- it is, like Nature is still believed to be, "great and small, splendid, secret, and terrifying" (cited in Benjamin, 1999: 690). The sublime, as one seeks to see dialectics, slips into service, fills a wrapper, settles into a container or fills packaging suited for the wild put to work in an age of mechanical reproduction.

Benjamin speculated the great Parisian panoramas were efforts to perfectly imitate Nature. With scaffoldings of iron, light, and entertainment transpose in the wilds and woods "a thousand configurations of life, from enduring edifices to passing fashions" what is the systemic secret cue, or "the advent of machines" (Benjamin, 1999: 4-5). In one conjuncture, photography, panoramas, and proletarianization produces deceptively industrialized changes in the physical landscapes of the Earth itself as enduring edifices for the randonneur to explore in search of the wild. Where once, as Benjamin claims, "one sought tirelessly, through technical devices, to make panoramas the scenes of a perfect imitation of nature" (1999:5) in the era of the Arcades, the era of the Cascades finds technical devices used continuously to perfect the accessibility and convenience of everyday industrial life in the material settings of wilds, woods, and waters. Stabilized as predictable panoramic packages for repeated use, as Leopold suggests, these engineered experiences are accepted as living in harmony with Nature, an authentic trophy of contact with the wilds, or sublime outdoor leisure. Nonetheless, as the Cascades web page hints, "a few ghosts of the old trail remain -stone steps that survive the flood but now lead nowhere." These are manufactured trails one must tread to realize what is afoot here.

As the department store served as "the last promenade for the flâneur," where all "his fantasies were materialized" beyond the Arcades of Paris, one finds beyond Pearisburg in the Cascades how the Department of Agriculture opens up promenades for the randonneur and his/her industrial tourism where the skills of a flâneur "that began as art of the private individual ends today as necessity for the masses" (Benjamin, 1999: 895). Again, seeing dialectics here, such "exhibitions of the natural world "truly" propagate the universe of commodities" (Benjamin, 1999: 894) now proliferating as Planet Earth in the Anthropocene.

The dream world of the Cascades is not unlike that of the Arcades, even though they vary in time, place, mission, and pace. Under the gas greenhouse, this swath of Nature itself is little more than a commodity -- both as the packaged wilds and the processed past -- brought together in bureaucratic ruination by behavioral policing, educational direction, and environmental agitation. The citification of the country, the deruralization of the woods, the deanimation of wildlife, and the denaturalization of the outdoors reeks from the detrital deposits of constant weeding, brush clearing, animal trapping, tree pruning, trail surfacing, car-park policing, and boundary marking. The green governmentality in "Hiking to the Cascades" is a frozen freedom loaded with determinate mission requirements: no littering, take lots of photos, no leafleting, walk on the right, no smoking, stay on the trail, no drugs, watch out for dogs/children/wheelchairs, no alcohol, keep your clothes on, no fires, careful swimming, no rock climbing, never go to the top of the falls, no loud music, converse with strangers, no shooting, lower your voices, no rock throwing, do not remove anything from the park, no soliciting, leash your dog, no loitering, and, finally, of course, to each and every hiker "please enjoy your visit."

Here one recognizes the activities enjoyed at the Cascades by the dreaming collective, which knows no history, and accepts the apparent permanence of the wilds as both "the eternal return of the same" as well as "the sensation of the newest and most modern" efforts at wilderness preservation. To paraphrase Benjamin, the sense of space that parallel this perception of time is "the interpenetrating and superposed transparency of the world" trodden by the randonneur (Benjamin, 1999: 546). Most expect the wilderness at work in the age of mechanical reproduction to remain "always the same" to betoken the enduring qualities of the biosphere, while in coincident happenstance bureaucratic machinery develops a secure and stable "same as always" quality-controlled mechanical reproducibility 
in the outdoors experience being commodified.

Many days, then, the Cascades trail is choked with foot traffic as each randonneur remains intent on that perfect photograph, pleasant picnic or personal-best powerwalk. The oppressive openness of the outdoor recreationists' conduct of conduct charges the air with wish images of a hike in the woods that reconnects them as hikers with their historical heritage, need for the natural or love for life. Yet, there is a heavy sense of ruination, loss, and obsolescence as the gaggles of government guests march through this exurbanized outside turned suburbanized inside. The walls are invisible but real, the ceiling is unseen but dropping, the floor is rugged but manufactured, the doors are open but limited, and the windows are many but mostly closed. Through them, does one only see to the same wish-images, dream-pictures, fantasy-views of a deadening liberal democratic government service and horrendous industrial capitalist commodity: the nature preserve. [5]

The cascadification of arresting sites in the countryside express "images in the collective consciousness in which the old and new interpenetrate" by deflecting the imagination of all this is new, like urban industrial society, with strange "images of its successor, the latter appears wedded to elements of primal history < $\underline{\text { Urgeschichte }}>-$-- that, to elements of a classless society" (Benjamin, 1999: 4). Similarly, the frontier fellowship of all America expanding ever outward in fulfillment of its Manifest Destiny seemingly restores the rich classless fantasy of liberty, equality, and fraternity on the trails in the woods. It has taken many decades, but the fetish character of capitalism envelops the spatiality of the Cascades as well as the Arcades. They both concretize "the anticipation and imaginative expression of a new world" (Benjamin, 1999: 637,) congealing in the environmentalization of the planet.

Even though it is not a city, not a building, and not inside, the Cascades constitute a type of full-blown capitalist interior design, crystallizing its built environments in a micrology of the planet's overall citification as a macrology. Since this state park/national forest seems dream-like, do its fixtures, flows, and features express key characteristics of contemporary cultural, economic, and social structures standing ready to be deciphered by seeing dialectics? The dream worlds of the Cascades with all their layered traces plausibly are as rich and ragged as the dream worlds of the Arcades. As the web page asserts, "it takes four bridges and innumerable stone steps and walkways to give visitors this experience." One need not only investigate the major metropolis as a "landscape of noisy life" (Benjamin, 1982: 1056) to experience the shocks of modernity. Few cityscapes reconfigured for quiet leisure can disclose as much about the marginalization, fragmentation, and organization of late capitalist experiences as these meandering paths on the trail to the Cascades. If one engages in seeing dialectics, then the striding randonneur will reveal as much as a wandering flâneur. The allegedly wild, in fact, offers faint hope for any escape from the reified repetition of fetishized commodification.[6]

The green utopian aspirations of state parks are as riddled with the same modes of betrayal found in metropolitan centers: the relentless repetition of experience swirling about as a mystified "newness." Each hike to the Cascades, every visit to a bevy of state parks, all contact with the dazzling array of outdoors excitements are but another phantasmagoric commodity. Novelty is not truly "newness" in some genuine regard. It is only different variegated unconscious sense of "newness" out on sale at many elsewheres or otherdays. Consequently, the Cascades express in their own articulations "that which is 'always-again-the-same'," (Benjamin, 1982: 1038), with their entangled mythological joys and disappointments, promises and betrayals, escapes and endlessnesses.[7]

Intriguingly, cascadification near Pearisburg, and elsewhere in many other American landscapes, emerges out of the same vertiginous characteristics of the nineteenth century, after industrial machines leave their imprints on private and public individual existences. The Cascades are an "illumination" not only in a theoretical manner, by an ideological transposition, but also in "the immediacy of their perceptible presence" (Benjamin, 1999: 14) since they appear to coast among the mobilization of people and things beyond cities where machines made their advent. Their citification comes as the market colonizes the countryside as well, and, arguably, more so as these exploding centers of commodification draw down the stocks of Nature.[8]

Cascadification, then, congeals multiple phantasmagoria of industrial-era ecotectures, interpolating grand staircases in hillsides with stone, spanning cataracts and canyons with timber and rope bridges, and reconfiguring the terrains of the wilds into stylized built environments. As sites worthy of preservation for consumption via mass movements of visitors, viewers, and voyagers in Paris, the anthropogenic dammed, farmed, mined, timbered, or ranched spaces of the countryside around Pearisburg capture the same dynamics. Here, the "always the same" must be visited and viewed frequently on millions of voyages to sustain all these occluded developments with affirmations of "same as always."

Both cascadification and arcadification can be quickly turned into the detritus of history, in which the halfconcealed traces of daily life for "the collective" can be reviewed with "the methods of the nineteenth-century 
collector of antiquities and curiosities" (Eiland and McLaughlin in Benjamin, 1999: ix). It is the work of the wild, in part, to circulate continuously as tokens of the Earth's antiquity as well as curios of its ever-evolving biota. Therein lies for many the lure of wilds, the mystery of the woods, the tranquility of waters.

The iron architectures of industrial tourism turned city and country inside out as arcadification fuses with cascadification. Where many once visited panoramic displays in cities of nature's wonders, the diorama attains displaced purity in natural settings. As Benjamin (1999: 530) archly observes, "in the same year in which Daguerre invented photography, his diorama burned out. 1839." A walk down the streets of Paris or up the trails outside Pearisburg, becomes a voyage to, though, and for the enjoyments of a transposed dioramic experience. Prior photographs, which have illuminated these passage ways, in turn, affirm "the fact that film today articulates all problems of modern form-giving-understood as questions of its own technical existence" (Benjamin, 1999: 530), since the Cascades' many destinations - hiking trails, stone steps, scenic overlooks, and camping grounds all are experimental panels of an embedded dioramic consciousness in concreto open for continuous reaffirmation as "points of (photographic) interest." Cascadification is another material manifestation of the "historical and dialectical relation between diorama and photography" (Benjamin, 1999: 848).

This era of art dawns decades after the Arcades' hey-day when the Cascades' designs capture a glow from Jugenstil - the modern decorative styles collectively clustered with the Second Industrial Revolution -- as various new "youth" or "modern" fashions recur in the Art Nouveau, Arts and Crafts, Mission, Stil Mucha or other organic design articulations. In its most perverse reactionary form, it can appear as Futurism, Art Moderne or even Suprematism, but these expressions remain a "reactionary attempt to sever technologically constituted forms from their functional contexts and turn them into natural constants -- that is, to stylize them" (Benjamin, 1999: 558). Cascadification brims with dioramic, symbolic, and iconic stylizations as one recognizes during these material transformations how "the bourgeoisie begins to come to terms with the conditions - not yet, to be sure, of its social domination-but of domination over nature” (Benjamin, 1999: 558).

The collective dream life of capitalist cultivators is drawn to the Cascades, because when they are most awake many among the masses tend to value only the tillable utility of land. One can also witness this shift in Giles County by seeing dialectics. [9] As Leopold notes, there is a culture of "clean farming" across the USA in which ignorant croppers ask, "what good is it" (Leopold, 1966: 190) of native fauna and flora without seeing their harmonious coexistence within the whole land organism. The same can be said of clean ranching, building or settling. When he asks, "if the biota, in the course of aeons, has built something we like but do not understand, then who but a fool would discard seemingly useless parts" (Leopold, 1966: 190). In turn, the citifying engines of corporate agriculture, town planning, and extractive commerce with planetary urbanization prove themselves to be the trades of fools.

Leopold's walks typify those to be taken by the land-ethical citizen. On these wanderings in rural Wisconsin, he exults in having "all the acres I can walk over," when he checks up on his coinhabitants — the oriole, the wren, thrasher, blue bird, cardinal, towhee as well as the mink, raccoon, bobcat, rabbit, skunk — as "we sally forth, the dog and I, at random" (Leopold, 1966: 44, 46). He saunters down creek beds, hikes up sand hills, treks through pine lots, and trudges through snow banks. Whether hiking after grouse, partridge or goose, Leopold and his dog meander across the land on their randonné through its ruination. At the same time, he laments the invasions of starlings, Russian thistles, carp, and cheat grass in the American West, Leopold feels loss in those derelict ruins of the land. On his hikes, he finds "the hopeless attitude almost universal. There is, as yet, no sense of pride in the husbandry of wild plants and animals, no sense of shape in the proprietorship of a sick landscape. We tilt at windmills in behalf of conservation in convention halls and editorial offices, but on the back forty we disclaim even owning a lance" (Leopold, 1966: 168).

Cascadification expresses a hard parsing of this chaos as "land" slips into stark styles of economic exploitation, while "country" remains indirectly less exploited but nonetheless abstract, reified, and manufactured essentially under other mystified conditions of production. Leopold (1966: 177) distinguishes them:

Land is the place where corn, gullies, and mortgages grow. Country is the personality of land, the collective harmony of its soil, life, and weather. Country knows no mortgages, no alphabetical agencies, not tobacco road; it is calmly aloof to these petty exigencies of its alleged owners. ... Poor land may be rich country, and vice versa.

Leopold's small Sauk County family spread of 120 prairie acres in Wisconsin, as he records, was once quite extraordinary. Up until about 1840, it had basically soils, fauna, and flora identical to those going back to the last ice age 12,000 years ago. As rich country, the animals, plants, soils, and microorganisms thrived there through twelve millennia "of living and dying, burning and growing, preying and fleeing, freezing and thawing, built that dark and 
bloody ground we call prairie" (Leopold, 1999: 193).

Around 1840, sod-busting wheat farmers and private owners pushing west brought the rapacious constructs of "land" in their eagerly engineered "clean farming" to the prairie's "country." Within two generations, Sauk County decayed into the detritus of development. As only some patches become "good land," much of the prairie deteriorated into "poor country," which now suffers erosion, alien species, desiccation, engineered infrastructures and, finally, educated landscaping. The hyperurbanizing experts and engineers intent upon extracting the maximum crop yields from their new-found lands, as Leopold complains,

killed off the prairie fauna and they drove the flora to the last refuge of railroad embankments and roadsides. To our engineers this flora is merely weeds and brush; they ply it with grader and mower. ...The prairie garden becomes a refuge for quack grass. After the garden is gone, the highway department employs landscapers to dot the quack with elms, and with artistic clumps of Scotch pine, Japan Barberry, and Spiraea. Conservation Committees, en route to some important convention, whiz by and applaud this zeal for roadside beauty (1966: 193).

The urban must recast the Earth as citified land and country with neither spatiality being ultimately at peace. With this "wholesale artificialization of the landscape" (Leopold, 1966: 200), the gas greenhouse grows apace. Fossil fuel-sourced fertilizer, pesticide, herbicide and energy inputs simply accelerate "clean farming."

Cascadification takes hold here and there, and "what remains of our native fauna and flora remains only because agriculture has not got around to destroying it. The present ideal of agriculture is commodification: "clean farming means a food chain aimed solely at economic profit and purged of all non-conforming links, a sort of Pax Germanica of the agricultural world" (Leopold, 1966: 199). All around the Cascades, clean farming also gained control in Giles County, leaving ruins and remnants of good country popping out only here and there. As Leopold (1966: 125) frets on his "Illinois Bus Ride," all that clean farmers have done is "make Illinois safe for soybeans," so he stares out the bus windows at troubling signs of other times and places: "in the narrow thread of sod between the shaved bands and toppling fences grow the relics of what once was Illinois: the prairie. No one in the bus sees these relics." As with the prairie, so too is it with the Appalachian Highlands. Once the urbanizers capture country space, they create vast tracts of "land" on the prairies and in the highlands. Giles County also is full of "good land" for clean farming, but many fewer parts of it are left as "good country," even around the Cascades.

As Benjamin might note, the Cascades mark yet another reinvention of industrial society. Now greenhouse gas-roofed, their apparently unsullied expanses extend everywhere beyond, behind, beneath or beside the world's industrial environment of buildings. Their owners, managers, and residents might hold them, separate and apart, from the built environments fabricated by the human agents at work in all forms of clean building, farming, ranching or settling as the never-to-be-built, yet-to-be-built or once-built environment. This only cloaks them in claddings of the wild, the big outside or maybe Nature. As sites, stocks and services, the Cascades are a non-city. Yet, as citified and deruralized space in which multiple users seek to find everything they need, the Cascades capture the citified spectacular and sublime, lit from above through the gas greenhouse that the Earth's global commerce produces.

\section{Conclusion: Seeing Dialectics}

Even though green politicos and environmental thinkers still represent the deserts and mountains as America's last wilderness, the sheer numbers of campers/climbers/hikers/trekkers clambering around their peaks and valleys for decades already are the best sign of "the wilderness" becoming thoroughly mangled with "the urban"? This experimental mapping of Benjamin's Passagen-Werk into a critique of the countryside's citification shows how the great urban boulevards rise at the same time in modernity as the rarest grand buttes get identified as worth the hike. Like the Arcades, the Cascades are turned old, out, and over in markets as their unnamed natural vitality is engineering away in planning and packaging.

Whether as peaks or prairies, "national legislation removed native and pastoral peoples and designated the heights as sites of recreational use, scientific study, and aesthetic inspiration" (Schrepfer, 2005: 2) to pound out "nature preserves." Romantic souls want wilderness to be desolate, remote, threatening, and mysterious, but do the rising tides of recreationists coming by the hundreds, thousands, and then millions only want to consume other varieties of fabricated exurbanization? Cutting primitive paths through the pines essentially builds bucolic boulevards out into the boondocks for a subjectivity not unlike a flâneur. And, the ways of Abbey's or Leopold's randonneur 
are just celebrating other stylized engagements with sport, leisure, and entertainment not unknown on many big city streets.[10]

Ruggedizing, wildernessing, preserving or parking these spaces all requires complex manufactured spatiality. The Cascades are, like the Arcades, by-passed, worked-round, and passed-over domains. Prevented from being always submitted to constant extractive uses, they are made busy and quiet at the same time as attractive industry sites. As buttes and boulders become but just another by-pass or boulevard, the citification of space proceeds along with the commodification of pace and place in Nature.

As Agger's fast capitalist critique of late capitalist cultural representation affirms, many unrecognized kinds of identity, if not unity, flow together at sites like the Cascades. When Benjamin observes, "the property appertaining to the commodity as its fetish character attaches as well to the commodity -- producing society as it represents itself and thing to understand itself" (Benjamin, 1999: 669), he anticipates how the age of ecological decline will manifest itself in the Anthropocene. Benjamin and Leopold disclose how and why capitalist exchange is far from natural, but it is not yet wholly artificial. Its "natural history" petrifies today in "ecological modernization." For such sustainable development schema, the daily drift of materiel makes its meaning, the weekly whirl of exchange is its system, the monthly calculus of commerce generates its service, and the yearly account of ruination is its artifact.

\section{Endnotes}

1. Benjamin surveyed nineteenth century industrial cultures as they took their form around Paris. One today, however, must review late twentieth and early twenty-first century industrial culture as it has taken form in the planet itself. Indeed, seeing dialectics should scan carefully seriously the debris of mass culture from both the city and country, indoors and outdoors, boulevards and trails, machines and markets as their coevolutionary urbanaturalization become more apparent with each passing year. How the planet itself is choking everywhere on the debris of mass culture -from the gasses fabricating an evermore greenhoused planet to the sprawling shanty-towns reconstructing the Earth as a planet of slums to the tangles of man-made plastic detritus stretching for miles and miles in mobile marine marshes of garbage that swirl around mid-ocean the world's seas. Like Benjamin's Passagen-Werk, which aspired to become "a materialist philosophy of history: rooted in "the utmost concreteness" (cited in BuckMorss, 1989: Benjamin, 1982/1929), can this exercise continue that project on considerably different and more contemporary, but still parallel and quite critical, lines of critique?

2. The parallels between an arcade and a cascade are enthralling. An "arcade" is a series of arches forming a gallery, which can be erected for decorative purposes or to create a roofed passage way lined with shops such as those studied by Benjamin. Coming to English as "arcade" from French via the Italian "arcata," it goes back to Latin's "arcus" -- "arch" or "bow." In turn, a "cascade" is a series of waterfalls, or a grand deluge of dropping water, chemicals, lace, events or any successive advance of stages, processes, activities. Also coming to English from French, it arrives via the Italian "cascata" from a verb "cascare" -- to fall in Latin, or "cadere." One must tend, however, the word root -- "-cade," which also implies via its French, Italian and Vulgar Latin origins "flowing," "rolling," or "falling" in fluid stages. Like an industrial process, divided labor united in final product, the flight of goods and services to buyers and sellers, does modernity bond them together in arcades and cascades. Whether citified or countrified, reification erodes away the solidities of once might have been "lifeworld" in the streams of what are now the flows of "system."

3. The east slopes drain into the Atlantic via the James River and the Chesapeake Bay, while the waters coming west down from Mountain Lake through Little Stony Run over the Cascades waterfall flow into the New River that ultimately joins the Ohio River, then the Mississippi, and eventually the Gulf of Mexico. What Benjamin had with Paris in the Old World at the core of urbanized Europe, here one has outside Pearisburg, Virginia in the New World near a U.S. governmentdesignated wilderness high in the Appalachian Mountains in one of Virginia's least populated and less prosperous counties (per capita income in 2000 was $\$ 18,396$ for 16,657 people in 360 square miles). Remote, rugged, and rural, it also is, nonetheless, quite denaturalized. Citified, organized, policed, reified, and packaged in nearly invisibilized fashions, Cascade Falls closely parallel the Arcades, which arose in the Old World in Paris amidst the urban, national, and industrial revolutionization of France.

4. The lands around Cascade Falls rose out of the Earth's seas towards the close of the Mississippian Age eons ago. Largely limestone, millennia of winds, glaciations, and floods have eroded away over a mile of material off these parts as the Appalachians aged. While Native American settlements go back over 10,000 years, all that is left are stray artifacts, lost 
settlements, and many burial sites. European explorers made contact with the indigenous nations, and one of the first signs of subsequent European pioneering is a marker in Glen Lyn that records: "Mary Porter killed by the Indians November 28, 1742." At the small village of Eggleston, which is not far from where Big Stony Creek runs into the New River, Adam Harmon founded this first permanent, and still existing, town in 1745. Named after William Branch Giles, one of Virginia's first Congressmen (1790-1815), and then Governor of the Commonwealth (1827-1831), the county has been sliced and diced multiple times in annexations and removals from 1806 to 1861 when it became a border jurisdiction butted against the breakaway state of West Virginia in the Civil War. Played out mines, abandoned farms, stone building ruins, lost villages, forgotten Confederate forts, closed factories, abandoned stone quarries, overgrown roads, and dying Appalachian crossroads dot the landscape. So amidst these ruins, those still remaining, or just visiting, all are caught up in today's global economy in new, and often, more tentative ties that depend upon recreationists, retirees, and realtors to boost the isolated county's flagging fortunes by tinkering around the Cascades.

5. Often as canned as any stale sit-com, as organized as any prison-yard break, as scripted as any TV infomercial, as controlled as any shackled jail inmate headed to court, the once "Big Outside" is now a much cozier miniature "insidified-outside." So too are outdoor recreationists entangled by indoor routines all reproducing the reifications of industrial capitalist commodification within invisible walls. The Giles County web page assures all for scenes that are "both breathtaking and beautiful" with "both power and beauty," it is vital that "the falls are also fairly easy to view." Such are the fearsome features on the face that so many now celebrate as "sustainable development." In fact, it might only be the latest of highest stage of global and local cosmetic surgeries on the visage of accumulation without end. If one hopes, like Benjamin, is to be a "physiognomist" of capitalism in today's greenhoused global environments where clues for scrutinizing social life must be deciphered from the materiality, structure, and disposition of buildings themselves, as Benjamin aspired to do with the Parisian Arcades, then comparable opportunities await one at these Appalachian Cascades. For an up-to-date feel to this approach toward the spectacularization of nature in which the narratives advance to the point of bringing the viewer from anywhere to the site itself, see: http:// virginiasmtnplayground.com/cascades/

6. Putting a mild Heideggerian spin on the question might help. Does the randonneur come to the Cascades trail in the spirit of Gelassenheit able to enjoy some full "letting-be"? Or is the randonné upon which so many are launched to finish at the Cascades express the programmatic agenda of "system" rather than "lifeworld"? Perhaps "the worlding of the world" here is already one of environmentality? On the one hand, does one find that Das Welt weltet? Or instead does Das Umwelt umweltet in the disciplinary grids of a green Gleichschaltung? The trails out to the Cascades perhaps are all standing reserves whose technics are embedded in the reproduction of accumulation without end (Heidegger, 1962, and, Heidegger, 1977)? Their artful engineering embedded in the Earth express the dynamic unfolding package of industrial tourism: its openness is constrained, its relationality is narrow, its worldness is processed, and expansive governmentality is fully mapped out by the reproduction of wilds in an age of mechanical work. The worlding of the world is already always here and there, but is its finite being framed in the processed, packaged, programmed spatialities of a full-blown gas greenhouse?

7. Benjamin argued the "link to the entertainment industry is significant" (1999: 14). Arcadification, then, mobilizes entertainment along with multiple visions of its enjoyment for "the advent of machines" (Benjamin, 1999: 16). This mode of productive force deployment Benjamin reconnects to the "History of Civilization" keyed to "humanity's life forms and creations" in manners that enable him "to show how, because of this reifying representation of civilization, the new forms of behavior and the new economically and technologically based creations that we owe to the nineteenth century enter the universe of a phantasmagoria" (Benjamin, 1999: 14).

8. Again, reasoning along parallel lines, there is within a generation or two-say beginning in earnest with the Third Republic in France or just after the close of Reconstruction in the U.S.A.- a boom in the massmarket tourist trade made possible by iron railroads, iron steamships, and iron infrastructures. Getting to the Cascades is key, and their reconstitution as individual passages, voyages, adventures brings out "the world at large" rather than in miniature. The Cascades are, in turn, major expressions of industrial lighting of a new kind-photography. Its illumination, reproduction, celebration in endless panoramas lit old natural sites in a new mechanical sight. Yet, the infiltration of iron, steel, and concrete into the city and country brought a new aesthetics of authenticity tied to timber, stone or rope on the terrain itself.

9. Many well-intentioned thinkers sing high praises to "the dreams of the Earth" (Berry, 1989); but, the latest contrivances for sustainable development on Earth as a gas greenhouse indicate that one must be cautious here. When remembering such dreams on the trails to the Cascades, are those dreamers of Earth in today's capitalist collective striding back and forth to the Cascades, like those strolling through the Arcades, simply to be enthralled in today's new dream worlds of accumulation without end? Their peculiar collective unconsciousness perhaps reveals what Buck-Morss sees as a double sense of unawareness: "on the one hand, because of its distracted dreaming state, and on the other, because it was unconscious of itself, composed of atomized individuals, consumers who imagined their commodity dream-world to be uniquely personal (despite all objective evidence to the contrary) and who experienced their membership in the collective only in an isolated, alienating sense, as an anonymous 
component of the crowd" (1989: 260).

10. For trekkers on this faraway trail in Giles County, Virginia, do they revel in their dreamy experiences, and are they perhaps only as promising, unique personal, and universal as many meanderings through some major suburban megamall closer to home? For the masses, the leisure market, or the hiking public composing the great society of bureaucratically-controlled consumption, the promised sublime of natural settings drains away in the systematicity of artificial spatialities. Without constant commodification, all the way down and around the world, once surrounded within a "designated recreation area," it is soon the case that as "the rebus image of the commodity," even these sylvan hollows and rushing streams are "the always-again-the-same in great masses" (Benjamin, 1982: 429), since the best surprise for these consumers is that there is no surprise.

\section{References}

Abbey, Edward. 1968. Desert Solitaire: A Season in the Wilderness. New York: Ballantine.

Abbey, Edward. 1977. The Journey Home: Some Words in Defense of the American West. New York: E.P. Dutton.

Abbey, Edward. 1982. Black Sun. New York: Avon.

Adorno, Theodor W. 1970. Über Walter Benjamin, hrsg. Rolf Tiedemann. Frankfurt am Main: Suhrkamp Verlag.

Adorno, Theodor W. 1984. "The Idea of Natural History," Telos, 60 (Summer): 111-124.

Agger, Ben. 2011. Body Problems: Running and Living Long in a Fast-Food Society. New York: Routledge.

Agger, Ben. 2004. Speeding Up Fast Capitalism: Cultures, Jobs, Families, Schools, Bodies . New York: Routledge.

Agger, Ben. 1992. The Discourse of Domination from the Frankfurt School to Postmodernism. Evanston, IL: Northwestern University Press.

Agger, Ben. 1991. A Critical Theory of Public Life: Knowledge, Discourse and Politics in an Age of Decline. New York: Routledge.

Agger, Ben. 1989a. Soci(onto)logy: A Disciplinary Reading. Urbana: University of Illinois Press.

Agger, Ben. 1989b. Fast Capitalism: A Critical Theory of Significance. Urbana: University of Illinois Press.

Benjamin, Walter. 1999. The Arcades Project . Cambridge, MA: Harvard University Press.

Benjamin, Walter. 1997. One Way Street. London: Verso.

Benjamin, Walter. 1986. Reflections, ed. Peter Demetz. New York: Schocken Books.

Benjamin, Walter. 1985. The Origin of German Tragic Drama. London: Verso.
Benjamin, Walter. 1983. Charles Baudelaire: A Lyric Poet in the Era of High Capitalism . London: Verso.

Benjamin, Walter. 1982. Gesammelte Schriften, V, hrsg. Rolf Tiedemann and Herman Schweppenhauser with T. W. Adorno and Gershom Scholen. Frankfurt am Main: Surkamp Verlag.

Benjamin, Walter. 1982 [1929]. "Letter to Gershom Scholen," March 15, Gesammelte Schriften, V: 1091.

Benjamin, Walter. 1974-91. Gesammelte Schriften, I-VII, ed. Rolf Tiedemand and Herman Schweppenhäuser with T. W. Adorno and Gershom Scholem. Frankfurt am Main: Suhrkamp Verlag.

Benjamin, Walter. 1969. Illuminations, ed. Hannah Arendt. New York: Schocken Books.

Benjamin, Walter. 1969a. "These on the Philosophy of History," Illuminations: Essays and Reflections, ed. Hannah Arendt. New York: Schocken Books. 253-264.

Benjamin, Walter. 1969b. "The Work of Art in the Age of Mechanical Reproduction," Illuminations: Essays and Reflections, ed. Hannah Arendt. New York: Schocken Books. 217-251.

Brenner, Neil and Christian Schmid. 2014. "The 'Urban Age' in Question," International Journal of Urban and Regional Research, Vol. 38, no. 3 (May): 731-755.

Breeze, Paul A. 2005. Power Generation Technologies. London: Elsevier Science.

Buck-Morss, Susan. 1989. The Dialectics of Seeing: Walter Benjamin and the Arcades Project . Cambridge, MA: MIT Press.

Dunaway, Finis. 2005. Natural Visions: The Power of Images in American Environmental Reform . Chicago: University of Chicago Press.

Foucault, Michel. 1990. The History of Sexuality, Vol. I. New York: Vintage. 
Gilloch, Graeme. 1997. Myth and Metropolis: Walter Benjamin and the City. Oxford: Polity.

Heidegger, Martin. 1977. The Question Concerning Technology, and Other Essays. New York: Harper and Row.

Heidegger, Martin. 1962. Being and Time. Oxford: Blackwell.

Keller, Robert H. and Michael F. Turek. 1998. American Indians \& National Parks. Tucson: University of Arizona.

Lefebvre, Henri. 2003 [1970]. The Urban Revolution . Minneapolis: University of Minnesota Press.

Lefebvre, Henri. 1991. The Production of Space . Oxford: Blackwell.

Lefebvre, Henri. 1981. The Critique of Everyday Life, Vol. 3: From Modernity towards a Metaphilosophy of Daily Life . London: Verso.

Leopold, Aldo. 1966. A Sand County Almanac with Essays on Conservation from Round River. New York: Ballantine.

Luke, Timothy W. 2009. "Property Boundaries/Boundary Properties in Technonature Studies: 'Inventing the Future." Environments, Technologies, Spaces and Places in the TwentyFirst Century, ed. Damian F. White and Chris Wilbert. Waterloo, ON: Wilfrid Laurier University Press: 193-213.

Luke, Timothy W. 2007. "A Harsh and Hostile Land: Edward Abbey's Aesthetics, Ethics, and Politics in the Great American Desert," Telos, 141 (Fall): 5-28.
Luke, Timothy W. 2005. "Neither Sustainable nor Developmental: Reconsidering Sustainability in Development." Sustainable Development, 13, no. 4 (October), 228-238.

Luke, Timothy W. 1997. Ecocritique: Contesting the Politics of Nature, Economy and Culture . Minneapolis: University of Minnesota Press.

Luke, Timothy W. 1996. "Governmentality and Contragovernmentality: Rethinking Sovereignty and Territoriality after the Cold War," Political Geography, Vol. 17, no. 6/7: 491-507.

McNeill, J. R. and Peter Engelke. 2014. The Great Acceleration: An Environment History of the Anthropocene since 1945. Cambridge, MA: Belkamp/Harvard University Press.

Moore, Derek J. 2008. “A California Perspective on Outdoor Recreation Trends," Press Democrat (February 8).

Schrepfer, Susan R. 2005. Nature's Altars: Mountains, Gender and American Environmentalism . Lawrence, KS: University of Kansas Press.

Spence, Mark David. 1999. Dispossessing the Wilderness: Indian Removal and the Making of the National Parks . Oxford: Oxford University Press.

Stephens, Bradley. 2007. "Reading Walter Benjamin's Concept of the Ruin in Victor Hugo's Notre-Dame de Paris ," French Studies, Vol. LXI, no. 2: 155-166. 
